University of Nebraska - Lincoln

DigitalCommons@University of Nebraska - Lincoln

Faculty Papers and Publications in Animal

Science

Animal Science Department

November 1977

\title{
REPRODUCTIVE AND TESTICULAR CHARACTERISTICS OF PUREBRED AND CROSSBRED BOARS
}

\author{
E. R. Wilson \\ Oklahoma Agricultural Experiment Station, Stillwater \\ R. K. Johnson \\ University of Nebraska-Lincoln, rjohnson5@unl.edu \\ R. P. Wettemann \\ Oklahoma Agricultural Experiment Station, Stillwater
}

Follow this and additional works at: https://digitalcommons.unl.edu/animalscifacpub

Part of the Animal Sciences Commons

Wilson, E. R.; Johnson, R. K.; and Wettemann, R. P., "REPRODUCTIVE AND TESTICULAR CHARACTERISTICS OF PUREBRED AND CROSSBRED BOARS" (1977). Faculty Papers and Publications in Animal Science. 79.

https://digitalcommons.unl.edu/animalscifacpub/79

This Article is brought to you for free and open access by the Animal Science Department at DigitalCommons@University of Nebraska - Lincoln. It has been accepted for inclusion in Faculty Papers and Publications in Animal Science by an authorized administrator of DigitalCommons@University of Nebraska - Lincoln. 


\title{
REPRODUCTIVE AND TESTICULAR CHARACTERISTICS OF PUREBRED AND CROSSBRED BOARS ${ }^{1,2}$
}

\author{
E. R. Wilson, R. K. Johnson and R. P. Wettemann ${ }^{3}$ \\ Oklaboma Agricultural Experiment Station, Stillwater 74074
}

\begin{abstract}
SUMMARY
One-hundred-ninety-five Duroc (D), Hampshire $(\mathrm{H})$, Duroc $\times$ Hampshire $(\mathrm{D} \times \mathrm{H})$ and Hampshire $X$ Duroc $(H \times D)$ boars were evaluated for reproductive performance. One-hundred-sixteen boars were castrated at approximately 225 days of age to evaluate testicular and epididymidal weights and sperm numbers. Testes from crossbred boars were $95.33 \pm 22.81$ $\mathrm{g}$ heavier $(P<.01)$ and contained $14.41 \pm 3.92$ billion more sperm $(\mathrm{P}<.01)$ than those from purebred boars. Testes from Hampshire boars were $50.40 \pm 31.75 \mathrm{~g}$ heavier with $6.27 \pm 5.45$ billion more sperm than those from Durocs. There were no significant differences between breeds for caput-corpus epididymidal measurements. Durocs had $24.55 \pm 12.16$ billion more sperm $(\mathrm{P}<.05)$ in the cauda epididymis than Hampshire boars. Testes weight and testes sperm numbers were significantly correlated with caput-corpus epididymidal and cauda epididymidal sperm numbers. Correlations of testicular and epididymidal characteristics with growth rate and backfat to $100 \mathrm{~kg}$ were small and nonsignificant.
\end{abstract}

Twenty 7.5-month to 9-month-old D, Dx H and $\mathrm{H} \times \mathrm{D}$ boars and $19 \mathrm{H}$ boars were each mated to two Yorkshire gilts to evaluate reproductive efficiency. Conception rates were: $D$, $63.2 \% ; \mathrm{D} \times \mathrm{H}, 67.5 \%$; $\mathrm{H} \times \mathrm{D}, 60.0 \%$; and $\mathrm{H}$, $48.6 \%$. Number of embryos 30-days postbreeding was $10.66 \pm .49$ and $11.25 \pm .43$ (P>.10) for gilts mated to purebred and crossbred sires, respectively. Twenty-eight of 36

\footnotetext{
${ }^{1}$ Journal Article 3193 of the Agricultural Experiment Station, Oklahoma State University, Stillwater. Research conducted by the Department of Animal Science and Industry (Project 1444).

${ }^{2}$ The authors express appreciation to Mr. James Holzer for technical assistance provided in collection of these data.

${ }^{3}$ Department of Animal Sciences and Industry, Oklahoma State University, Stillwater $\mathbf{7 4 0 7 4 .}$
}

crossbred boars mated each time they were exposed to an estrus gilt but only 11 of 36 of the purebred boars mated each time. None of the crossbred boars failed to mate more than once, while 15 of 36 purebred boars failed to mate two or more times. In general, differences among breed groups for time required to mount after exposure to estrus gilt and length of ejaculation time were small and nonsignificant. (Key Words: Male Reproduction, Crossbred Boars.

\section{INTRODUCTION}

Few research reports are available characterizing breeds of swine for male reproductive efficiency or evaluating the reproductive performance of the crossbred boar. Hauser et al. (1952) found that crossbred boars surpassed the parent lines in testis weight, epididymis weight, and stage of spermatogenesis. Swierstra (1968b) reported that there was no significant difference between 11-month-old Yorkshire and Lacombe boars for testis weight or for daily sperm production/gram net testis weight.

Evidence is inconclusive for evaluating the influence breed of service sire has on number of pigs born or conception rate. O'Ferrall et al. (1968) reported breed of sire effects were not significant for litter size or weight at birth, 21 or 56 days. Rahnefeld and Swierstra (1970) found that sire effects were significant in Yorkshire and Lacombe boars for number born alive and the number of pigs weaned per litter. Johnson and Omtvedt (1973) and Young et al. (1976b) found that sire and breed of sire effects were not significant for litter size 30-days postbreeding or at birth but were significant for litter size at 21 and 42 days of age.

This study was designed to evaluate Duroc, Hampshire and reciprocal cross boars for testicular and epididymidal development, fertility, litter size 30-days postbreeding, mating behavior and the relationship of growth and backfat 
with testicular measurements.

\section{MATERIALS AND METHODS}

The boars studied were born during fall 1973, spring and fall 1974 and spring 1975 at the Stillwater Swine Farm. Purebred Duroc and Hampshire herds have been maintained since 1969 with at least two new herd sires introduced each year. Crossbred boars were produced from reciprocal matings between randomly selected individuals from the purebred herds.

All boars were raised on a concrete floor from 8 weeks of age until reaching 100 kilograms. Boars were weighed off test weekly at which time they were probed for backfat and placed in dirt lots with 10 to 12 boars per lot. Six boars from each breed group (Duroc, Hampshire, Duroc $\times$ Hampshire and Hampshire $x$ Duroc) were randomly selected to be kept for the breeding phase of the study and the remaining boars were castrated as they reached 7.5 months of age. The distribution of boars by breed group is listed in table 1 . The mean age at castration was 229 days ( $\mathrm{SD}=3$ ). Boars were bilaterally castrated and the right testis was retained for evaluation. Testicular parenchymae, caput-corpora epididymides and caudae epididymides were weighed and homogenized in saline-Triton-Merthiolate fluid (Amann and Lambiase, 1969), and sperm numbers were determined in the tissues (Kirton et al., 1967). All values were multiplied by two to place on a boar basis.

Each of four breeding seasons for the repro-

TABLE 1. NUMBER OF BOARS BY BREED GROUP THAT WERE CASTRATED OR MATED

\begin{tabular}{lll}
\hline & $\begin{array}{l}\text { No. } \\
\text { boars } \\
\text { castrated }\end{array}$ & $\begin{array}{l}\text { No. of } \\
\text { boars } \\
\text { that } \\
\text { were } \\
\text { mated }\end{array}$ \\
\hline $\mathrm{D} \times \mathrm{D}$ & 31 & 20 \\
$\mathrm{D} \times \mathrm{H}$ & 35 & 20 \\
$\mathrm{H} \times \mathrm{D}$ & 23 & 20 \\
$\mathrm{H} \times \mathrm{H}$ & 27 & 19 \\
Total & 116 & 79 \\
\hline
\end{tabular}

\footnotetext{
${ }^{a} D=$ Duroc, $H=$ Hampshire, breed of sire listed
} first. ductive efficiency portion of the study began when the youngest boars had reached 7.5 months of age. The boars ranged in age from 7.5 to 9 months at the start of the breeding season which began approximately November 10 in the fall and May 1 in the spring. Six boars, which were littermates to one or more of the castrated boars, were used per breed group. All six boars were individually exposed to Yorkshire gilts until five had successfully mated with a gilt. Boars were randomly chosen across breed groups to mate with 7.5- to 9-month old gilts. Gilts were checked daily for estrus with a teaser boar. If a boar failed to mate, he was removed from the pen and a different boar was allowed to mate. When a boar mated with his first gilt, he was given a repeat breeding with the same gilt the following day. The same procedure was followed for the second gilt to which the boar was mated but no boar was allowed to mate with the second gilt until five boars per breed group had successfully mated with one gilt. All matings were made in a $5 \times 5$ $m$ pen with a concrete floor.

Time was recorded for two periods during each mating. Period 1 was the interval from when the boar entered the pen until he made a mount. Period 2 was the interval from intromission until the completion of ejaculation. The boars were given assistance only when it appeared that the mating would not be completed without assistance.

Approximately 30-days postbreeding the gilts which had not returned to estrus were slaughtered. The reproductive tracts were dissected to determine the number of embryos and the ovaries were examined for corpora lutea.

Least-squares procedures were used for analysis of testicular and epididymidal characteristics and mating behavior times. The model was: $Y_{i j k l}=\mu+A_{i}+S_{j}+D_{k}+(A S)_{i j}+(A D)_{i k}$ $+(S D)_{j k}+(A S D)_{i j k}+e_{i j k l}$ where $Y_{i j k l}=$ the observed trait of the $1^{\text {th }}$ boar from the $i^{\text {th }}$ season, $\mathrm{j}^{\text {th }}$ breed of sire and $\mathrm{k}^{\text {th }}$ breed of dam; $\mu=$ population mean; $A_{i}=$ fixed effect of the ith $^{\text {th }}$ season; $S_{j}=$ fixed effect of the $j^{\text {th }}$ breed of sire; $D_{k}=$ fixed effect of the $k^{\text {th }}$ breed of dam; $(A S)_{i j},(A D)_{i k},(S D)_{j k}$ and (ASD) $)_{i j k}$ represent the respective interactions, and $\mathrm{e}_{\mathbf{i j k l}}$ is the random effect associated with the ijk ${ }^{\text {th }}$ observation. For the analysis of number of embryos, the linear and quadratic regressions on number of corpora lutea were added to the model. Correlations among traits were obtained from 
within season and breed group corrected sums of squares and cross products and pooled across subclasses.

Intervals for mount and ejaculation for the first and second gilt mated to each boar were first analyzed separately. Differences between times were small and nonsignificant. Also, the correlation for interval to mount for the first and second gilt mated to each boar was .02 while the correlation for interval for ejaculation was .11; therefore, the data were pooled. This increased the number of boar records since each boar could be represented one or two times. Since correlations among intervals for gilts mated to each boar were small, this should not bias the error variance. Ejaculation time was not recorded the first season so the number of records for mount times is not equal to the number for ejaculation time.

Mating behavior data (number of successes and failures of a boar to mate when exposed to an estrus gilt) were collected in the last three seasons. The median test (Conover, 1971) was used to analyze these data. Conception rate was analyzed by chi-square (Steel and Torrie, 1960).

\section{RESULTS AND DISCUSSION}

Testicular and Epididymidal Cbaracteristics. Season, breed of sire and the interaction of breed of sire by breed of dam were significant sources of variation for most testicular and epididymidal traits. Season effects were significant for all testicular measurements and all epididymidal measurements except caputcorpus epididymis weight. Breed of sire of boar was significant for testicular weight, caputcorpus epididymidal and cauda epididymidal weight. Breed of sire by breed of dam of boar interaction, an indication of heterosis, was significant for testicular weight, number of testicular sperm and cauda epididymidal weight.

The breed group means for testicular characteristics are presented in table 2 . The crossbred mean testicular weight of $685.0 \mathrm{~g}$ was $16 \%$ heavier $(\mathrm{P}<.01)$ than the purebred mean of 589.7 grams. Testicular weights were not significantly different for Hampshire and Duroc boars (614.9 and $564.5 \mathrm{~g}$, respectively). Swierstra (1968b) reported mean testis weights of $349.1 \mathrm{~g}$ and 389.1 for 11-month-old Yorkshire and Lacombe boars, respectively, which were not significantly different.
Crossbred boars had $25.1 \%\left(14.4 \times 10^{9}\right)$ more testicular sperm $(\mathbf{P}<.01)$ than purebred boars. Testicular sperm numbers for Duroc and Hampshire boars were not significantly different. Wettemann et al. (1976) observed $104 \times$ $10^{9}$ total testicular sperm in yearling Yorkshire boars. Sperm numbers for the purebred and crossbred boars in this study were 55 and $69 \%$, respectively, of this value. This would suggest that these boars were not sexually mature. Sperm concentrations (testicular sperm no./ testes weight) were not significantly different between breed groups. Therefore, it appears that the increased sperm numbers in crossbred boars are mainly a function of increased testes weight and not due to heterosis for increased sperm production per gram of tissue.

Crossbred boars had $5.28 \pm 4.30 \times 10^{9}$ more caput-corpus epididymidal sperm than purebred boars and Hampshires had $7.15 \pm 5.98 \times 10^{9}$ more sperm than Durocs (table 2), although differences were nor significant. The cauda epididymides of crossbred boars were $6.7 \pm$ $3.29 \mathrm{~g}$ heavier $(\mathrm{P}<.05)$ and tended to have a higher sperm count. Duroc boars had $24.55 \pm$ $12.16 \times 10^{9}$ more sperm $(\mathrm{P}<.05)$ than Hampshire boars in the cauda epididymis and a higher sperm concentration.

There are several possible explanations for increased testicular sperm in crossbreds compared to purebreds even though epididymal sperm numbers were not significantly different. Since these are young boars that are still maturing, they may be producing sperm at different rates (Amann, 1970). If this is the case, the crossbred boars may be increasing sperm production faster than purebreds, but these sperm may not have arrived in the epididymis or traveled through the epididymis since epididymal transit time is approximately 10 days (Swierstra, 1968a). This may also explain the differences in the Durocs and Hampshires where Hampshires tend to have more testes sperm numbers, but the Durocs have significantly more total epididymidal sperm. Sampling and measurement errors may also be involved.

A more explicit explanation may be that the epididymis has the capacity to store a similar number of sperm regardless of breed and that excess sperm are reabsorbed in the epididymis or are excreted through the urine. Amann and Almquist (1962) suggest that in dairy bulls the cauda epididymis is the site of sperm reabsorption. They estimate that more than $57 \%$ of 


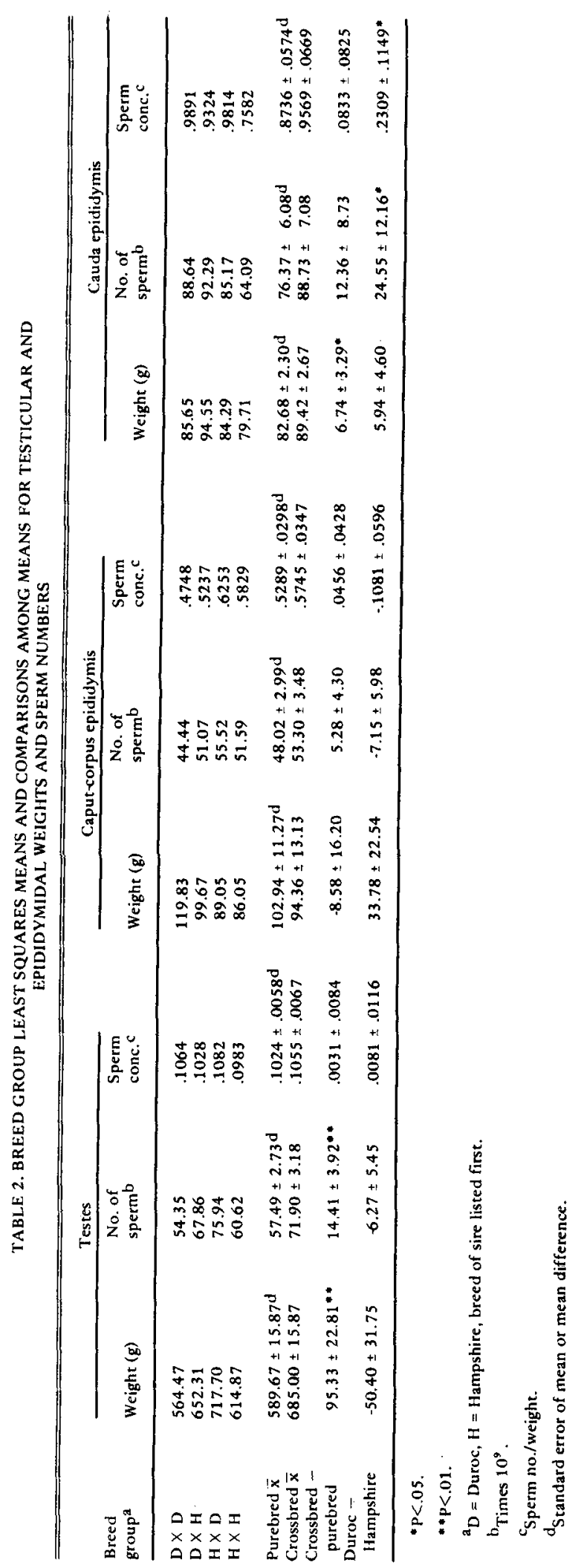




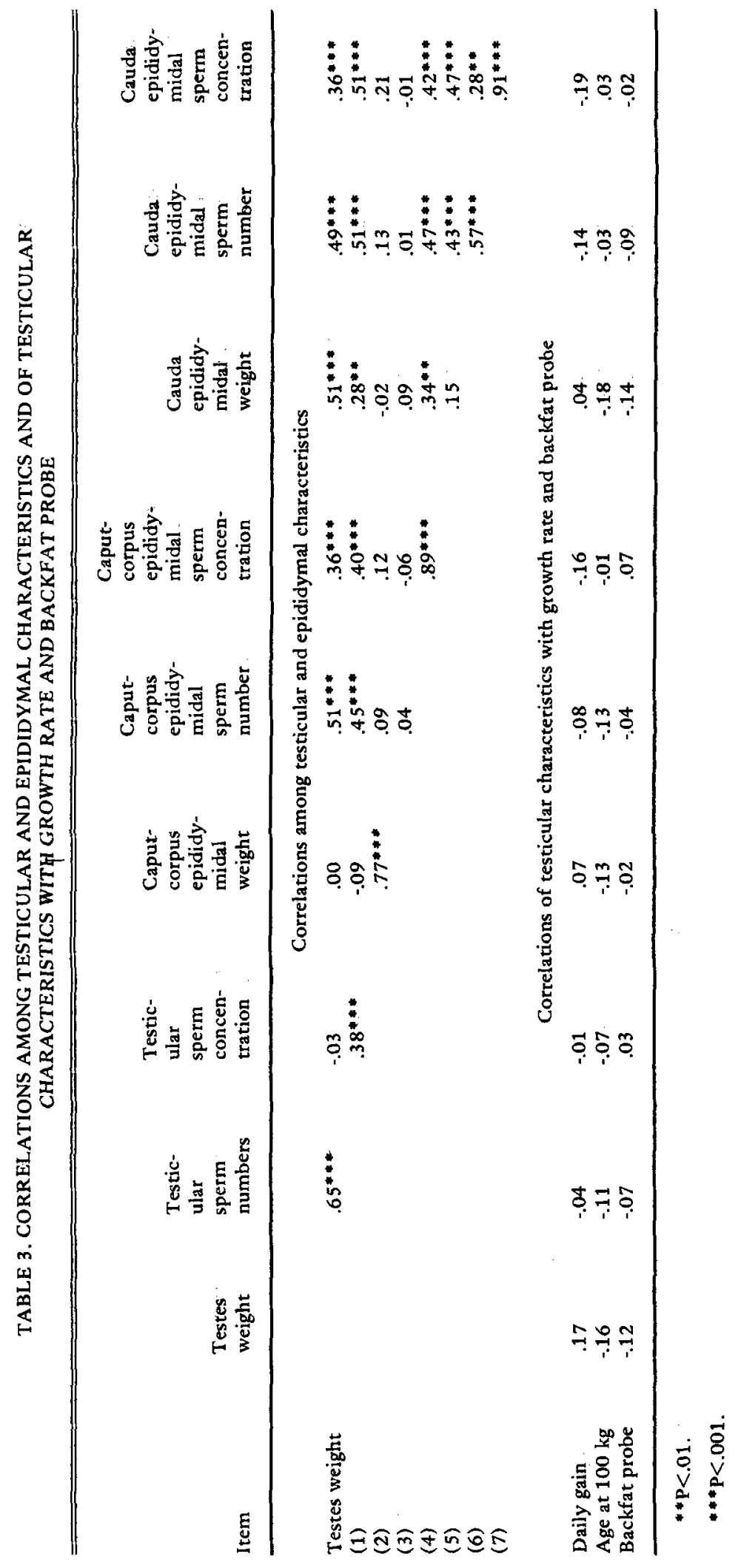




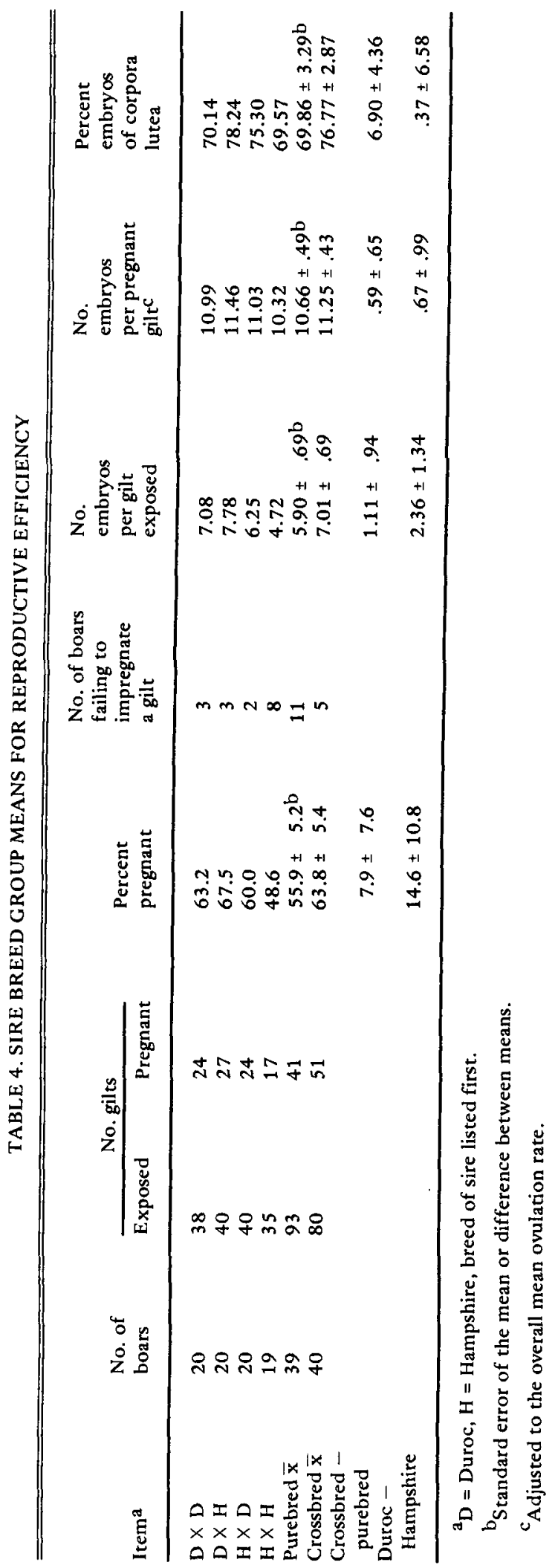


TABLE 5. MATING BEHAVIOR FOR BOARS OF EACH BREED GROUP WHEN EXPOSED TO AN ESTRUS GILT

\begin{tabular}{|c|c|c|c|c|c|c|}
\hline \multirow[b]{2}{*}{$\begin{array}{l}\text { Breed } \\
\text { group }^{a}\end{array}$} & \multirow[b]{2}{*}{$\begin{array}{l}\text { Total } \\
\text { no. } \\
\text { boars }\end{array}$} & \multicolumn{5}{|c|}{ No. of boars that } \\
\hline & & $\begin{array}{l}\text { Mated a } \\
\text { gilt each } \\
\text { time } \\
\text { exposed }\end{array}$ & $\begin{array}{l}\text { Had one } \\
\text { failure } \\
\text { to mate }\end{array}$ & $\begin{array}{l}\text { Had two } \\
\text { failures } \\
\text { to mate }\end{array}$ & $\begin{array}{l}\text { Had three } \\
\text { failures } \\
\text { to mate }\end{array}$ & $\begin{array}{l}\text { Had four } \\
\text { or more } \\
\text { failures } \\
\text { to mate }\end{array}$ \\
\hline $\mathrm{D} \times \mathrm{D}$ & 18 & 3 & 7 & 5 & 1 & 2 \\
\hline $\mathrm{D} \times \mathrm{H}$ & 18 & 16 & 2 & 0 & 0 & 0 \\
\hline$H \times D$ & 18 & 12 & 6 & 0 & 0 & 0 \\
\hline$H \times H$ & 18 & 8 & 3 & 4 & 0 & 3 \\
\hline
\end{tabular}

${ }^{a} \mathrm{D}=$ Duroc, $\mathrm{H}=$ Hampshire, breed of sire listed first.

sperm produced are reabsorbed in bulls which were ejaculated eight times per week and $97 \%$ of sperm production is reabsorbed in bulls at sexual rest.

Testicular weight is significantly correlated with all testicular and epididymidal characteristics except testicular sperm concentration and caput-corpus epididymidal weight (table 3 ). The correlation coefficients of testicular weight with testicular sperm numbers, caput-corpus epididymidal sperm numbers and cauda epididymidal sperm numbers were $.65, .51$ and 49, respectively. The correlations of testicular sperm numbers with caput-corpus epididymidal and cauda epididymidal sperm numbers were .45 and .51 , respectively. Almquist and Amann (1961) reported a correlation of .65 between testicular weight and testicular sperm numbers in mature, sexually-rested dairy bulls.

Hauser et al. (1952) suggests that testis growth is highly associated with body weight. Boar weights at castration were not recorded so the only estimate of body size is daily gain and days to $100 \mathrm{~kg}$ along with backfat probe at 100 kilograms. The crossbred boars gained $.10 \pm .02$ $\mathrm{kg} /$ day faster $(\mathbf{P}<.001)$ than purebred boars; similarly, Duroc boars gained $.07 \pm .02 \mathrm{~kg} / \mathrm{day}$ faster $(\mathbf{P}<.001)$ than Hampshires. Hampshires had $.45 \pm .10 \mathrm{~cm}$ less probe backfat $(\mathrm{P}<.001)$ than Durocs. There was virtually no difference between purebreds and crossbreds for probe backfat at 100 kilograms. These breed differences agree well with those reported by Young et al. (1976a) for barrows and gilts. The correlations of testicular and epididymidal characteristics with growth rate, days to $100 \mathrm{~kg}$ and backfat probe were small and nonsignificant (table 3). Correlations between testicular and epididymidal characteristics and age at castra- tion were very small as would be expected since little difference existed among boars in age at castration.

Reproductive Efficiency. There was no significant difference between breed groups for the percent of gilts pregnant (table 4). The crossbreds had a $7.9 \%$ higher conception rate than purebreds; however, this was due mainly to the $14.6 \%$ lower conception rate for Hampshire boars compared to Duroc boars.

Crossbred boars sired $1.11 \pm .94$ more embryos per gilt exposed than purebreds and Duroc boars sired $2.36 \pm 1.34$ more embryos per gilt exposed than Hampshire boars. Duroc boars were similar in this trait to crossbreds. Much of the low performance of the Hampshire boars for number of embryos per gilt exposed can be attributed to eight out of $19(42 \%)$ of these boars that failed to settle a single gilt.

The linear and quadratic partial regressions of number of embryos on number of corpora lutea were significant; therefore, breed group embryo number means were adjusted to the overall mean ovulation rate. Litter characteristics were not significantly affected by breeding of boar; however, crossbred boars sired litters which had $.59 \pm .65$ more embryos per pregnant gilt than purebred boars. Embryo survival rate (percent embryos of corpora lutea) was $76.77 \pm 2.87$ for litters by crossbred boars compared to $69.86 \pm 3.29$ for litters by purebred boars. Survival rates are below the $84 \%$ reported for Hampshire $\times$ Yorkshire and Duroc $x$ Yorkshire matings in an earlier study (Johnson and Omtvedt, 1973). The failure of breed of sire to be significant for embryo numbers is consistent with Reddy et al. (1958) and O'Ferrall et al. (1968) who reported nonsignificant breed of sire effects for litter size 


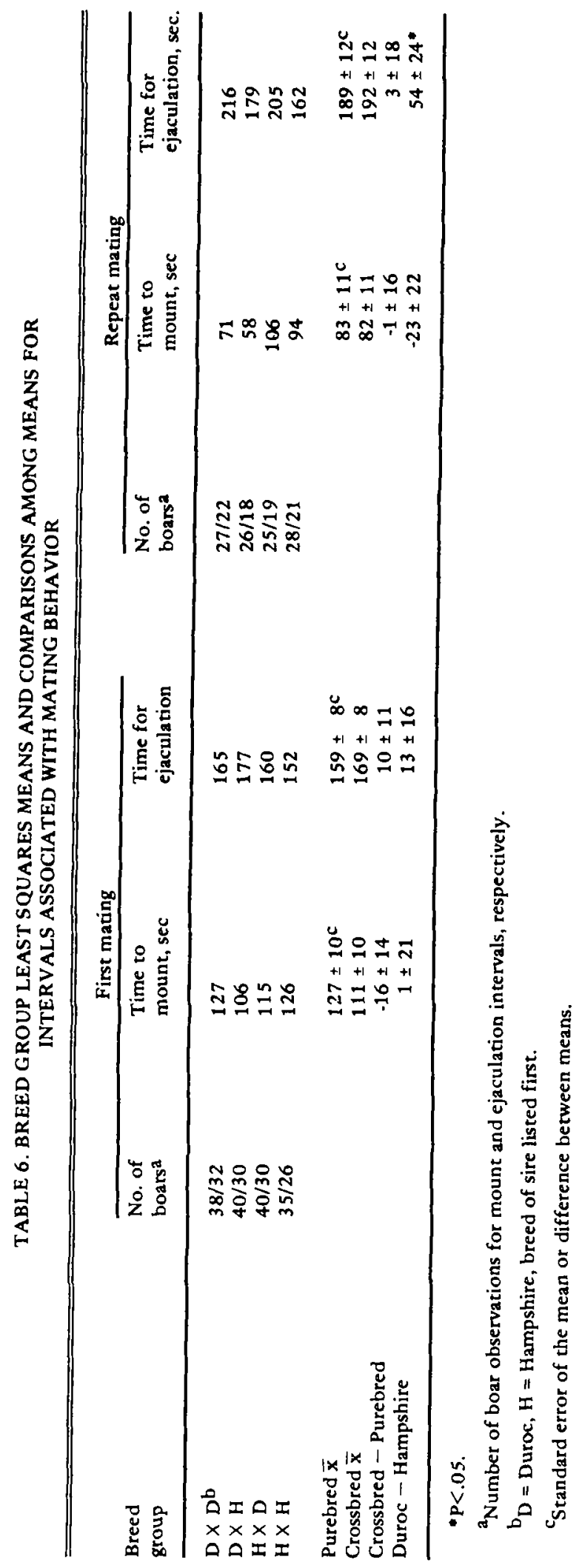


at birth, 21 days or 56 days. Johnson and Omtvedt (1973), however, found a significant breed of sire effect for number of pigs in a litter at 21 and 42 days. In the same study they observed no significant difference among breeds of sire for number of embryos at 30-days postbreeding.

Mating Bebavior. Mating behavior of crossbred boars was significantly different $(P<.001)$ from that of purebred boars (table 5). Twentyeight of the crossbreds mated every time they were exposed to an estrus gilt and eight failed one time. Only three of the Durocs and eight of the Hampshires mated every time. None of the crossbred boars had more than one failure to mate while $15(42 \%)$ purebred boars had two or more failures. Dewsbury (1975) reported that the proportion of inbred parental male rats that failed to mate in a series of four consecutive mating tests was much greater than the proportion of the $F_{1}$ males that failed the test.

There was little difference among breed groups for interval from exposure to an estrus gilt to mounting or for ejaculation time (table 6 ); however, Duroc boars ejaculated $54 \pm 24 \mathrm{sec}$ longer $(\mathrm{P}<.05)$ on the second mating than did Hampshires. Both purebred and crossbred boars mounted faster and ejaculated longer on the second day a gilt was in estrus (repeat mating) than the first day. Since crossbred boars had fewer failures to mate and tended to mount faster on the first mount, it appears that crossbred boars are quicker to mount. However, once the purebreds have mounted a gilt there is little difference between the breed groups in length of time for ejaculation or in time required for additional mounts.

There was a large amount of boar variation for intervals measured during mating $(\mathrm{SD}=$ 84.9 and $73.8 \mathrm{sec}$ for mount and ejaculation times, respectively). This study suggests that unless a more descriptive method to quantify mating behavior is developed the inherent and environmental causes of boar variation will make it very difficult to study sexual behavior or to adequately relate male sexual activity to other measures of reproductive efficiency.

\section{LITERATURE CITED}

Almquist, J. O. and R. P. Amann. 1961. Reproductive capacity of dairy bulls. II. Gonadal and extra- gonadal sperm reserves as determined by direct counts and depletion trials; Dimensions and weight of genitalia. J. Dairy Sci., 44:1668.

Amann, R. P. 1970. Sperm production rates. In A. D. Johnson, W. R. Gomes and N. L. VanDemark (Ed.) The Testis. Vol. 1. Academic Press, New York. p. $433-482$.

Amann, R. P. and J. O. Almquist. 1962. Reproductive capacity of dairy bulls. VI. Effect of unilateral vasectomy and ejaculation frequency on sperm reserves; aspects of epididymal physiology. J. Reprod. Fertil. 3:260.

Amann, R. P. and J. T. Lambiase, Jr. 1969. The male rabbit. III. Determination of daily sperm production by means of testicular homogenates. J. Anim. Sci. 28: 369.

Conover, W. J. 1971. Practical Nonparametric Statistics. John Wiley and Sons, Inc., New York.

Dewsbury, D. A. 1975. A diallel cross analysis of genetic determinants of copulatory behavior in rats. J. Comp. and Physiol. Psychol. 88:2, 713.

Hauser, E. R., G. E. Dickerson and D. T. Mayer. 1952. Reproductive development and performance of inbred and crossbred boars. MO. Agr. Exp. Sta. Res. Bull. 503.

Johnson, R. K. and I. T. Omtvedt. 1973. Evaluation of purebreds and two-bred crosses in swine: reproductive performance. J. Anim. Sci. 37:1279.

Kirton, K. T., C. Desjardins and H. D. Hafs. 1967. Distribution of sperm in male rabbits after various ejaculation frequencies. Anat. Rec. 158:287.

O'Ferrall, G. J. More, H. O. Hetzer and J. A. Gaines. 1968. Heterosis in preweaning traits in swine. J. Anim. Sci. 27:17.

Rahnefeld, G. W. and E. E. Swierstra. 1970. Influence of the sire on litter size in swine. Can. J. Anim. Sci. 50:671.

Reddy, V. B., J. F. Lasley and D. T. Mayer. 1958. Genetic aspects of reproduction in swine. MO.Agr. Exp. Sta. Res. Bull. 666.

Steel, R. G. D. and J. A. Torrie. 1960. Principles and Procedures of Statistics. McGraw-Hill Book Co., New York.

Swierstra, E. E. 1968a. Cytology and duration of the cycle of the seminiferous epithelium of the boar. Duration of the spermatozoan transit through the epididymis. Anat. Rec. 161:171.

Swierstra, E. E. 1968b. A comparison of spermatozoa production and spermatozoa output of Yorkshire and Lacombe boars. J. Reprod. Fertil. 17:459.

Wettemann, R. P., M. E. Wells, I. T. Omtvedt, C. E. Pope and E. J. Turman. 1976. Influence of elevated ambient temperature on reproductive performance of boars. J. Anim. Sci. 42:664.

Young, L. D., R. K. Johnson, I. T. Omtvedt and L. E. Walters. 1976a. Postweaning performance and carcass merit of purebred and two-breed cross pigs. $J$. Anim. Sci, 42:1124.

Young, L. D., R. K. Johnson and I. T. Omtvedt. 1976b. Reproductive performance of swine bred to produce purebred and two-breed cross litters. J. Anim. Sci. 42:1133. 